\title{
THE IMPLEMENTATION OF TAI TYPE COOPERATIVE LEARNING WITH PEER TUTOR TO IMPROVE STUDENTS' ACHIEVEMENT ON INDONESIAN LANGUAGE
}

\author{
Nyoman Setori Yuliastini \\ SMP Negeri 1 Seririt, Bali, Indonesia \\ Email: nyoman.setori@gmail.com
}

\begin{abstract}
This present study aims at improving students' achievement in Indonesian language through tai type cooperative learning with peer tutor in the academic year of 2015/2016. This study is a classroom action research and takes place at SMPN 1 Seririt from September to November 2015. It undergoes preliminary study to the action. A total number of 34 students consist of 16 female and 18 male are purposefully selected as the sample of this study. The researcher focuses on the evaluation on the first cycle and the second cycle after implementing technique. This study results in finding out that tai type cooperative learning with peer tutor has successfully improved students' achievement on Indonesian language in the academic year of 2015/2016. This is reflected by the improvement of the students' score with $85.29 \%$ of them have fulfilled the criteria of success in the first cycle. Nonetheless, there are $94.12 \%$ students who passed the criteria of success.
\end{abstract}

Keywords: cooperative learning, TAI, achievement

\section{Introduction}

In this global era, nations with competitive human resources have the opportunity to be developed countries, but not with the low competitive ones. The quality of human resources will not be able to compete if they do not take into account to this matter. Furthermore, education is closely related and be one of the alternatives to solve this problem. Education is expected to create qualified human resources. Government, in this respect, needs to promote education and ensure that every citizen has an access to education evenly as stated in the constitution of Indonesia (UUD 1945). This shows that the founders of Indonesia as a country believe that this nation will be a developed country and being detached from all kinds of colonialism.

Indonesian government has demonstrated a number of efforts to improve the quality of education particularly on social science subject. One of the efforts is that by revising the 1994 curriculum to be a competencebased curriculum, which later is revised again to be standard based curriculum. In fact, the implementation of standard based curriculum has not yet been successfully implemented in the learning process, yet it cannot be fully changed.

A visionary constructed educational curriculum is must though it is not easy to be described. There are various predictions about the future life. It includes the vision of the future with regard to intelligent predictions about the present and the trend is likely to occur in the life of the 21 st century. One of the essences that can be taken into account is planning a curriculum that enables learners to have a high order thinking skills, being able to solve problems, to be innovative, creative, and to live together in harmony. This will also help learners to have accessible occupation.

A revision of a curriculum in this country must be based on the constitution of ministry of education and culture (Permendikbud 160, 2014) about the application of standard based curriculum and K-13 (Curriculum 2013). Its revision should also be based on critiques and suggestions from various public instrument (civil society, professional associations, universities, schools) toward the ideas, documents, and the curriculum implementation which are monitored and evaluated by media. Indonesian present curriculum (Curriculum 2013) is developed and improved in these following aspects: (1) Directing the learning process to be a student-centred approach, (2) learners should have options regarding the materials and their learning style to have an equal competence, (3) strengthening the interactive learning process (students-teacher, society-environment), (4) building a network for students learning independently from others, (5) reinforcing the active learning (learners are equipped with the ability to finish task scientifically), (6) intensifying both independent learning and group work, (7) strengthening the multimedia-based instruction, (8) reinforcing the mass and classical instruction by consistently considering students' potential, (9) supporting learners with knowledge from other disciplines and (10) adapting the critical learning.

A shift in learning paradigm from teacher-centred to students-centred depends on teachers' understanding about basic educational theory that they follow to, including the perspective and teacher professional competence (Astuti, 2013). Generally, both teacher and students have the same role to develop the 
learning process in classroom. On the other, students' achievement is much influenced by the teacher's strategy in delivering materials. Therefore, teacher readiness plays a key role to the success of teaching and learning process. In other words, there is a relation between students' achievement and the method or strategy implemented by their teacher.

In fact, a number of 34 students who become the subject of this study get a low score during the preliminary study. It is proven from their summative test which averages in 68 . In order to solve this problem, an implementation of an innovative teaching strategy is necessary. In addition, teaching strategy is a specific way used by teachers/ researcher to be implemented in classroom which aims at avoiding learners from boredom, yet creating a comfortable learning atmosphere. An innovative teaching strategy also intends to attract students to be into learning more deeply.

An effective teaching should be followed by teacher's ability in mastering the components of the strategy. Teacher should also understand him/herself as the key role and has a crucial function to his/her subject. In addition, Indonesian ministry of education policy has stated that teachers should be able to adapt a learning strategy into their subject.

Besides, many teachers are not able to develop a learning strategy that attract students' attention and trigger them to learn. There are some skills that a teacher should have in conducting a teaching process. They are 1) questioning skill, 2) reinforcing skill, 3) skill to develop a backup plan, 4) explaining skill, 5) opening and closing skill, 6) leading a discussion skill, and 7) classroom management skill.

On the other hand, the Commission on Education of the 21st Century recommends four pillars of success in education. First, learning to learn, it covers how learners are able to seek of information around them. Second, learning to be, it expects learners to know themselves and be able to adapt with their surroundings. Third, learning to do, it expects learners to come up with ideas which are related to science and technology. Fourth, learning to live together, it covers how we should live in a society and in need of other human beings (Trianto, 2009).

An ideal learning process expects an intense and effective communication among teacher, students, and their environment. Yet, it does not only emphasize on what students should learn, but also on how they should learn it. A variety teaching strategy will prevent students' from boredom and enhance their understanding. A learning strategy is usually set as parameter to see how far learners can accept and apply the materials that their teacher has taught them.

Furthermore, learners' activity is also a critical factor in learning. This reminds that teaching and learning is a process of transferring knowledge from teacher to students, experiencing a learning activity so that there is an intense communication between teacher and students.

Cooperative learning has not been widely implemented in education, although the Indonesian people are very proud of mutual assistance in social life as their nature. Most teachers are reluctant to implement a system of cooperation in the classroom for several reasons. The main reason is learners do not learn if they are placed in group due to the inability of teacher to control them (Lie, 2007: 28). In addition, many people have a negative impression about the cooperative learning in groups. Many students are also unhappy when they are told to cooperate with others. Learners who are diligent felt compelled to work beyond the other students, while low achieving students feel inferior to be put in a group with students who are smarter.

The basis of cooperative learning is human as Hominid Socius. As social beings, human needs other people in their life. Cooperation is one way to interact each other and as a means to reach the same goal within community. In addition, the Vygotsky's theory regarding human zone of proximal development also state that people are in need of other people to grow together. In line with this theory, Piaget, also sees the importance of social activities cognitive development.

Thus, the researcher believes the solution to the aforementioned problems is by implementing cooperative learning. In this respect, the researcher uses the TAI type cooperative learning with peer tutor. Accordingly, this technique is suitable to be implemented during the discussion session in learning. It is also based on the constructivism theory that believes learning should be student-centred activities. This technique requires students to independently search for information, communicating it to the member of their groups so that they can work whether independently or in a group.

The researcher narrows the implementation of this strategy into Indonesian language as a subject taught in school. The main objective is to improve students' achievement in Indonesian language of the F class of eighth graders of SMPN 1 Seririt. Hypothetically, TAI type cooperative learning with peer tutor is able to improve students' achievement.

\section{Method}

This present study is a classroom action research which takes place in SMPN 1 Seririt from September to November 2015. As stated in Kemmis and Mctaggart model, this study covers preliminary study, planning, action, observing and reflecting it at the end of every cycle to decide whether or not this study is a success. There 
are 34 students who are purposefully selected as the subject in this study. They consist of 16 male students and 18 female.

There are some aspects observed in this present study. It covers the cognitive aspect such as the ability to identify problems, describing, and clarifying. The researcher utilises both quantitative and qualitative data to conclude the result of the study. Both data are presented descriptively. The qualitative data are obtained through the observation sheet, while the qualitative data are obtained through achievement test which is then measured through the adapted equation from Adnyani (2007:35).

In deciding the criteria of success, students' scores are converted into this following table:

Table 1 Guidelines for Conversion Score

\begin{tabular}{cccc}
\hline No. & Stretch of Value & Category & Description \\
\hline 1 & $81-100$ & A & Very Good \\
\hline 2 & $66-80$ & B & Good \\
\hline 3 & $56-65$ & C & Adequate \\
\hline 4 & $41-55$ & D & Poor \\
\hline 5 & $0-40$ & E & Very Poor \\
\hline & & & (Arikunto, 2005:211)
\end{tabular}

Based on the conversion of the scores, the researcher set some criteria of success to this study. The study is considered success if at least $75 \%$ from total students have passed the minimum requirement score which is 78 .

\section{Findings and Discussion}

During the preliminary study, it is gained that students' average score is 68 which means it is below the minimum requirement scores (78). Some students signify their struggle in learning, some to mention are misconception, hesitate to ask questions when they have problems. Further action to this result will also determine the success of this present study.

\section{Result of Cycle I}

Before implementing the strategy, the teacher starts with some preparation. Firstly, the teacher has further identification toward students' problem. Secondly, the teacher prepares the materials for two meetings with topic, "how to write a procedure to do something effectively". Thirdly, the teacher needs to arrange some instruments to support learning such as the worksheet, data collection instruments, and the observation sheet. Another preparation is on preparing syllabus, lesson plan, hand out, media, and relevant sources for the topic.

Moving to the action, it is started with teacher-student greeting. The teacher states the objective of the lesson. There is a question answered session. After that students need to pay attention on materials on procedure text as well as comparing it to other text types.

The application of this strategy starts with forming groups. In deciding the groups, teacher conducts a placement test. Teacher looks at the average score from daily test or the score from previous chapter to identify the weaknesses and the ability of learners. The groups are formed consisting of 4-5 heterogenic members from their ability, sex, race, and religion. There are total 6 groups formed consisting of four members and 2 groups with 5 members. The teacher explains the materials briefly and continued by assigning each group. In this respect, teacher also emphasizes that the success of each student is determined by how well they work within their group. It encourages students to work collaboratively. In this phase, teacher can also give personal guidance and assistance to each group. This activity is expected to make students to : a) be able to arrange their text in a good order, deliver it in good voice, intonation, pronunciation, and gestures, b) involve students in searching for information regarding the topic from any related and reputable sources, c)utilise related media, and sources, d) facilitate students to make a good arrangement of procedure text in an effective language, e) involve learners in every aspect of learning actively, f) facilitate interaction between teacher and students, and students with related source of information.

The materials are continued to the next meeting. In the next meeting, teacher divides students into two groups namely donor group and receptor group. Each member of these groups are put together as a peer tutor. Donor group, which tends to have better achievement, is put to the low achieving group. This grouping is conducted to let students to be confident as a tutor and guiding their friends. The roles of these groups are (a) each member of the group will be back to their original group, (b) each group is given chance to present the result of their group work. Teacher will give some comments and suggestion when necessary. Regarding the evaluation, teacher administers a test for all students. The test is done individually where the scores are announced after the test. The team recognition is done if a group has successfully finished the test with a good score. As for groups which cannot finish the task as expected will be labelled as okay group and other terms to (a) give a positive feedback and reinforcement orally or in form of a reward, (b) confirm the results of exploration and elaboration of learners through a variety of sources, (c) facilitate learners to reflect to experience what they have learned, (d) 
facilitate learners to gain meaningful experience in achieving the basic competencies: (e) rolling as a resource and facilitator in answering questions students when they face difficulties by using effective language; (f) help solve the problem; (g) provide a reference so that learners can check the results of exploration; (h) provide information for further exploration; (i) motivate students who lack or have not actively participated.

During the whole class unit, teacher holds a teacher conference where students can ask anything that they do not understand. Teacher's role is to clarify if there is a misconception, giving reinforcement, and conclusion. The detail of teacher's role is explained as follow: a) work collaboratively with students to conclude the lesson, b) conduct an assessment and / or reflection of the activities that have been carried out consistently and programmatically; (c) provide feedback on the process and learning achievement, (d) plan follow-up activities in the form of remedial learning, enrichment programs, counselling services and / or assign a task both individual and group tasks in accordance with the learning outcomes of students. The result of cycle 1 is shown in Figure 1.

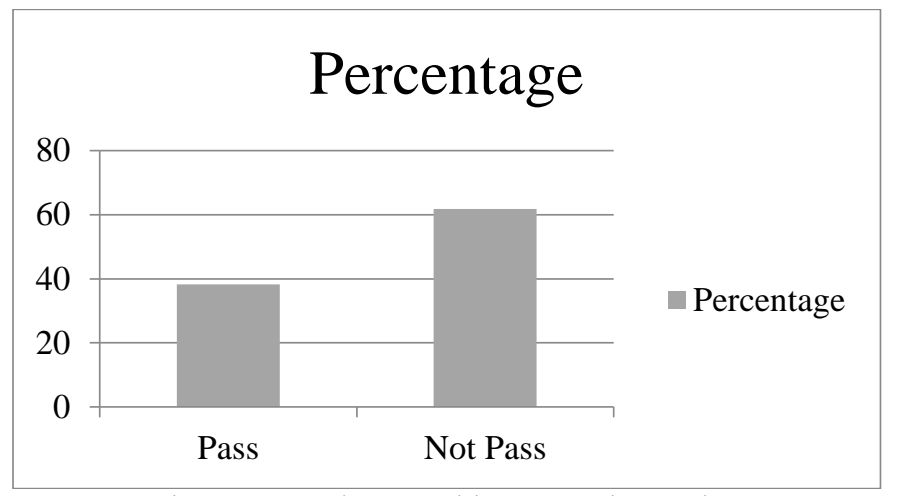

Figure 1. Students' achievement in Cycle I

Based on the result of calculation in cycle 1, it is gained that the average of students score is 76,92 with range of the lowest score is 65,38 and the highest one is 84,62 . Thus, there are only 13 students or $38,42 \%$ who pass the minimum requirement or fulfilling the criteria of success. Meanwhile, the other 21 students or $61,76 \%$ have not passed the minimum requirements. Since the percentage of students who passed the minimum requirement is below the criteria of success, the second cycle is needed. Here are some problems encountered in cycle one:

1) The formation of the group requires a lot of time, thus it reduces the time for discussion. The group should be formed before the implementation of Tai cooperative learning with peer tutors. However, the researcher has anticipated this problem for the upcoming cycle.

2) At the stage where students from donor group assists the receptive groups, they are not courage assist their friends. Even some tend to refuse to do it. In order to solve this matter, teacher needs to motivate the students more to make them courage become a tutor

3) The researcher found that not all learners are active during the group work. It is only learners who are considered more intelligent in their groups who actively participate, while others only participate as they think how far they should to. Therefore, assigning them an equal tasks is considered as a solution

\section{Result of Cycle II}

In this phase, teacher continues to discuss a topic about "appreciating a drama performance". Based on the teacher evaluation, teacher prepares a revised version of learning instruments, worksheets, and data collection instruments in the form achievement test. Teacher prepares lesson plans well in the form of a syllabus, lesson plans, hand out, media and sources relevant to the topics to be discussed. Similarly, the assessment will be done with process approach and achievement test based on the lesson plan.

To begin with, learners greet the teacher and the teacher responds it. Teacher displays examples of drama video who where students need to listen to it. Teachers and learners respond it by allowing learners to give opinions, criticisms, and suggestions at the beginning of learning.

Similarly to the first cycle, placement test is administered to learn the students' weakness on the learning objectives. The phase is continued by forming a group and students need to sit with their groups and work cooperatively. Each group is treated by the teacher. Teacher's role is to explain about drama and followed by having question and answer session. Teacher also reminds them that the success of each of them is influenced much by their cooperative work.

The students then work cooperatively to finish tasks given by the teacher, while teacher's role is to monitor and facilitate the difficult points of students work. This kind of activity expects students to be able to: a) facilitate other groups to construct a drama script, b) facilitate other students to perform their drama script, c) 
observe their friends' performance, d) assess their friends' performance, e) lead their friends in a discussion to explore new ideas, and f) facilitate learners in cooperative and collaborative learning, g) facilitate learners to communicate with their peer tutor comfortably, h) accommodate learners to construct a report on their exploration result individually or in group i) facilitate learners to present their work, j) facilitate learners to hold an expo, tournament, festival and other products, k) facilitate learners to have an activity that build their confidence. The result of students work is assessed by the teacher by collecting them, ad ask them to present it in the following meeting.

In the next meeting, each group gets a chance to perform their short drama in front of other groups. After students undergo all the process, the teacher determines the successful group and the unsuccessful group. The successful group will become the donor group while the other one becomes the receptive group. Each member of each group are put into peers to be a peer tutor. It is the role of the teacher to decide who will be into peers with who. After the tutor is conducted, the peers will be back into their original group. After they are put into peers to have tutoring phase, they need to go back to their original group, present their work in front of the class, teacher gives input if the students face a problem to answer their friends' question.

The assessment is conducted by administering a test to the students. Their score is then calculated to know their achievement. Team recognition is also necessary. For the low and high achieving students, the teacher labelled them as an okay group, amazing, or great. In this respect, teacher is expected to a) give proper feedback and reinforcement orally or in written form, b) confirming the students' work on the exploration and elaboration of their work, c) facilitate students to reflect to their experience during the treatment, d) facilitate learners as the source of information if they have any query regarding the lesson, motivate them to actively participate in a lesson. The result of second cycle is provided as follows:

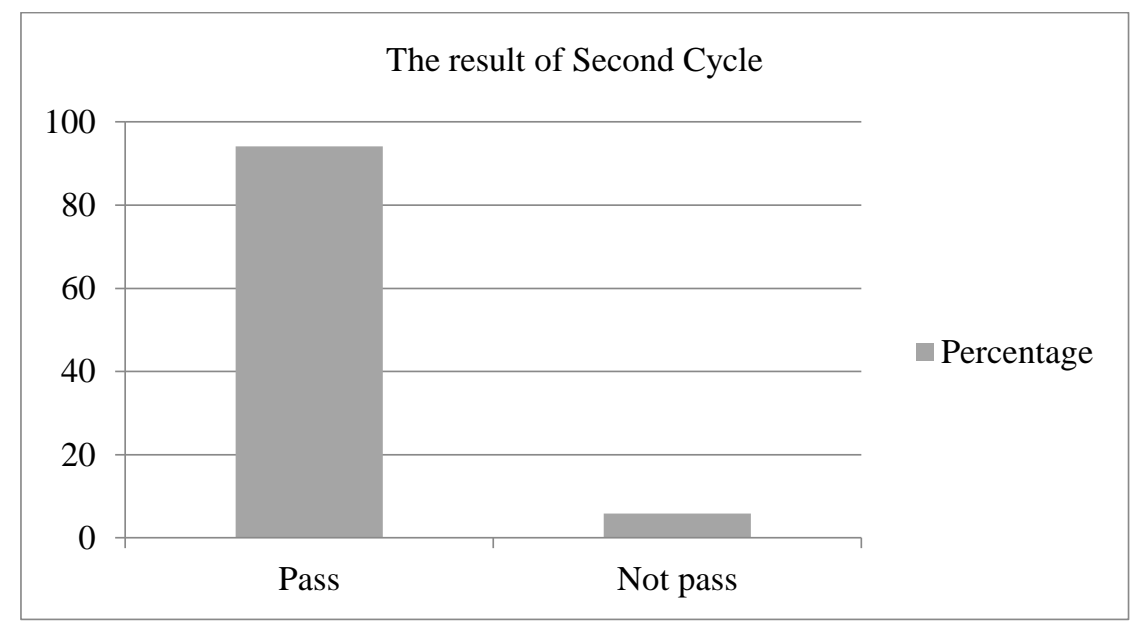

Figure 2. Students' Achievement during the Second Cycle

Based on the result of calculation in cycle II, it is gained that the students' average score is 85,71 with 71,43 as the lowest score and 92,86 as the highest score. There are total of 32 students or 94,12\% who passed the minimum score of fulfilling the criteria of success while the other 2 students or 5,88 \% do not pass the minimum requirements. This improvement is caused by several factors as follows:

1) The group that has been formed previously proceed to the second cycle.

2) Students from donor groups are motivated and convinced that they are worthy of being a peer tutor.

3) Teacher has prevented the possibility that some students will disturb or hinder the application of this strategy by making a commitment beforehand

4) To prevent dominance intelligent learners into groups, each group is required to share tasks so that all have the same opportunity to experience this strategy

Despite the improvement of students' achievement, there are two students who have not passed the criteria of success, it is suspected because both learners do not prepare well when following the learning and assessment process. 


\section{The Improvement of Students' Achievement from Cycle I and Cycle II}

The improvement of students' score from cycle I to cycle II is presented in the following table

Table 2. Comparison Data between Cycle I and Cycle II

\begin{tabular}{|c|c|c|c|c|}
\hline \multirow{2}{*}{ No. } & \multicolumn{2}{|c|}{ Score (1-100) } & \multirow{2}{*}{ Deference } & \multirow{2}{*}{ Description } \\
\hline & Cycle I & Cycle II & & \\
\hline 1 & 80.77 & 78.57 & -2.20 & Down \\
\hline 2 & 76.92 & 71.43 & -5.49 & Down \\
\hline 3 & 76.92 & 78.57 & 1.65 & Up \\
\hline 4 & 73.08 & 92.86 & 19.78 & Up \\
\hline 5 & 84.62 & 92.86 & 8.24 & Up \\
\hline 6 & 84.62 & 85.71 & 1.10 & Up \\
\hline 7 & 84.62 & 85.71 & 1.10 & Up \\
\hline 8 & 84.62 & 71.43 & -13.19 & Down \\
\hline 9 & 80.77 & 92.86 & 12.09 & Up \\
\hline 10 & 76.92 & 85.71 & 8.79 & Up \\
\hline 11 & 76.92 & 92.86 & 15.93 & Up \\
\hline 12 & 73.08 & 85.71 & 12.64 & Up \\
\hline 13 & 84.62 & 78.57 & -6.04 & Down \\
\hline 14 & 80.77 & 92.86 & 12.09 & $\mathrm{Up}$ \\
\hline 15 & 73.08 & 85.71 & 12.64 & Up \\
\hline 16 & 73.08 & 85.71 & 12.64 & Up \\
\hline 17 & 65.38 & 78.57 & 13.19 & Up \\
\hline 18 & 73.08 & 92.86 & 19.78 & Up \\
\hline 19 & 65.38 & 85.71 & 20.33 & $\mathrm{Up}$ \\
\hline 20 & 80.77 & 78.57 & -2.20 & Down \\
\hline 21 & 73.08 & 85.71 & 12.64 & Up \\
\hline 22 & 76.92 & 78.57 & 1.65 & $\mathrm{Up}$ \\
\hline 23 & 76.92 & 92.86 & 15.93 & Up \\
\hline 24 & 84.62 & 92.86 & 8.24 & Up \\
\hline 25 & 69.23 & 92.86 & 23.63 & Up \\
\hline 26 & 69.23 & 92.86 & 23.63 & Up \\
\hline 27 & 80.77 & 85.71 & 4.95 & Up \\
\hline 28 & 80.77 & 92.86 & 12.09 & Up \\
\hline 29 & 69.23 & 85.71 & 16.48 & Up \\
\hline 30 & 76.92 & 78.57 & 1.65 & Up \\
\hline 31 & 73.08 & 92.86 & 19.78 & Up \\
\hline 32 & 76.92 & 78.57 & 1.65 & Up \\
\hline 33 & 73.08 & 85.71 & 12.64 & Up \\
\hline 34 & 84.62 & 85.71 & 1.10 & Up \\
\hline
\end{tabular}

Based on Table 2, it was obtained that 5 students or $14.71 \%$ of total students lowered their scores, while 29 students or $85.29 \%$ of total students improve their achievement. It is also gained that students who have fulfilled the criteria of success is already above $75 \%(94,12 \%)$. 
The average score of the learning achievement of the first cycle and the second cycle are 76.92 and 85.71. In other words, there is a different score by an average of 8.79. It shows that the implementation of Tai cooperative learning with peer tutor is able to improve the learning achievement of eight grade students of SMP Negeri 1 Seririt in academic year 2015/2016 in Indonesian language subject

Based on the result of the study, TAI type cooperative learning with peer tutor has successfully improved the learning achievement of eight grade students of SMP Negeri 1 Seririt in academic year 2015/2016 in Indonesian language subject. This is influenced by some factors, some to mention are (1) Reducing disruptive behaviour and interpersonal conflicts; (2) low achieving students are helped consistently; (3) Students are taught how to work in a group; (4) students know how to develop their capabilities and skills; (5) There is a sense of responsibility in groups to solve problems; (6) effective and efficient of time allotment in the learning process; (7) This program can help students who have difficulties in understanding the learning materials; (8) Team Assisted Individualization help improve problem-solving abilities of learners and reduce the assumption of many students that Indonesian language is difficult; (9) In the cooperative learning with Team Assisted Individualization, learners are rewarded for their efforts; (10) It requires students to practice in a group and appreciate other's ideas.

\section{Conclusions}

Based on data from the research and discussion it could be concluded that: The implementation of TAI type cooperative learning with peer tutor improve the learning achievement of eight grade students of SMP Negeri 1 Seririt in academic year 2015/2016 in Indonesian language subject. This is proven by the improvement of the score of students' achievement which is $85.29 \%$ (over $75 \%$ ). In addition, the students who completed the second cycle also have exceeded $75 \%$, i.e. $94.12 \%$.

Based on the discussion that has been described above, the researcher provide readers with some suggestions, (1) teachers are suggested to use TAI type cooperative learning with peer tutors since it is proven in improving the learning achievement of students, especially for the Indonesian language teaching; (2) For future researchers, they can add the types of variables or implement TAI type cooperative learning in the broader scope or a different class; and (3) future researchers then need to pay attention to the results of the evaluation of the implementation of this strategy in both cycle I and II as consideration for further implementation of this technique

\section{References}

Agung, G. A.A. (1997). Pengantar Eavaluasi Pengajaran. Singaraja: STKIP Singaraja

Achmad, A. (2003). Implementasi Model Cooperative Learning dalam Pendidikan IPS di Tingkat Persekolahan. http:// www.depdiknas.go.id/jurnal/43/rusdy-a-siroj.htm. Access June $2^{\text {nd }} 2007$.

Adnyana, P.B. (2006). Pengaruh Penggunaan Model Siklus Belajar dalam Pembelajaran IPS terhadap Penguasaan Konsep, Penalaran, Dan Keterampilan Inkuiri Peserta didik SMP Laboratorium IKIP Negeri Singaraja. Jurnal Penelitian IKIP Negeri Singaraja.

Ardana, I M. et al. (2005). Implementasi Pembelajaran Kooperatif TAI Berorientasi Gaya Kognitif Sebagai Upaya Penyesuaian Strategi Pembelajaran Matematika dengan Kemampuan Peserta didik SD yang Beragam di Singaraja. Jurnal Penelitian IKIP Negeri Singaraja.

Arikunto, S. (2005). Prosedur Penelitian. Jakarta: Bima Aksara

Bundu, P. (2003). Pengaruh Evaluasi Formatif dan Gaya Kognitif Terhadap Hasil Belajar IPA. Jurnal edukasi. 4(1) pp. 31- 38 .

Candiasa, I M. (2002). Pengaruh strategi pembelajaran dan gaya kognitif terhadap kemampuan memprogram komputer. Dessertation (unpublished). Program Pasca Sarjana Universitas Negeri Jakarta.

Candiasa, I M. (2006). Pendidikan Berbhinneka. Disampaikan Pada Sidang Terbuka Senat Institut Keguruan dan Ilmu Pendidikan Negeri Singaraja. Monday, January $31^{\text {st }}$ 2006. Institut Keguruan dan Ilmu Pendidikan Negeri Singaraja.

Dewi, A.A.R. (2006). Penanganan Kelompok Bermasalah Melalui One By One Plus dalam Pembelajaran Kooperatif Berorientasi Gaya Kognitif sebagai Upaya Meningkatkan Interaksi dan Hasil Belajar Matematika Peserta didik Kelas VI SD Negeri 6 Banjar Jawa. Thesis (unpublished). IKIP Negeri Singaraja.

Hermayani, L. (2006). Implementasi Pembelajaran Kooperatif Tim Assisted Individualization (TAI) Berorientasi Gaya Kognitif sebagai Upaya Meningkatkan Kemampuan Komunikasi Matematika Peserta didik Kelas 5 SD Negeri 6 Banjar Jawa. Thesis (unpublished). IKIP Negeri Singaraja.

Liu, Y. \& Ginter, D. (1999). Cognitive Styles and Distance Education. http://www.westga.edu/ distance/liu23.html. Access November $2^{\text {nd }} 2007$.

Marguna, G. (2007). Pengaruh Model Pembelajaran Kooperatif dan Tipe Masalah Terhadap Kemampuan Berpikir Kritis Peserta didik Kelas X SMA Laboratorium Undiksha Singaraja Tahun Pelajaran 2006/2007. Thesis (unpublished). IKIP Negeri Singaraja. 
Musser, T. (1997). Individualdifferences: How field dependence-independence affects learners. http://www.personal.psu.edu/staff/t/x/txm4/paperl.html. Diakses tanggal 2 November 2007.

Nur, M. (2004). Teori-teori Pembelajaran Kognitif. Pusat Sains dan Matematika Sekolah, Universitas Negeri Surabaya.

Redhana, I W. \& Widana, S. (2002). Penerapan strategi pemecahan masalah dalam pembelajaran generatif sebagai upaya untuk meningkatkan kualitas pembelajaran kimia dasar pada mahapeserta didik TPB Jurusan Pendidikan Kimia IKIP N Singaraja tahun akademik 2001/2002. Research Report (unpublished). Fakultas Pendidikan MIPA, IKIP Negeri Singaraja.

Redhana, I W. (2003). Meningkatkan keterampilan pemecahan masalah dan pemahaman mahapeserta didik Jurusan Pendidikan Kimia Fakultas Pendidikan MIPA IKIP Negeri Singaraja melalui metode pembelajaran kooperatif dan open-ended laboratory praktikum biokimia I pada tahun akademik 2002/2003. Research Report (unpublished). IKIP Negeri Singaraja.

Arsana, R.( 2007). Penggunaan Diskusi Kelompok Untuk Meningkatkan Motivasi Belajar Peserta didik Kelas XI IPS III SMA Negeri 2 Singaraja. Thesis (unpublished). Jurusan Bimbingan Konseling Fakultas Ilmu Pendidikan Undiksha Singaraja.

Sanjaya, W. (2006). Strategi Pembelajaran Berorientasi Standar Proses Pendidikan. Jakarta: Kencana

Sardiman A.M. (2001). Interaksi dan Motivasi Belajar Mengajar. Jakarta: PT. Raja Grafindo Persada.

Slavin, R. E. (1995). Cooperative learning $2^{\text {ed }}$. Needham Height, Masachuetts: Allyn and Bacon.

Slameto. (2003). Belajar dan Faktor-faktor yang Mempengaruhinya. Rineka Cipta : Jakarta

Suparno, P. (1997). Filsafat Konstruktivisme dalam Pembelajaran. Kanisius : Yogyakarta

Yasa, R. (2005). Pengaruh Pembelajaran Kooperatif TAI dengan Penanganan Kelompok Bermasalah Melalui One By One Plus terhadap Kemampuan Komunikasi Matematika Peserta didik Kelas VII SMP Negeri 3 Singaraja. Thesis (unpublished). IKIP Negeri Singaraja. 